\section{A Banl RFLP at a deletion hotspot in the human dystrophin gene}

\author{
Andrew P.Read and Roger Mountford \\ Department of Medical Genetics, St Mary's \\ Hospital, Manchester M13 0JH, UK
}

Source/description: Cf56a is a $0.9 \mathrm{~kb}$ EcoRI fragment of dystrophin cDNA in pUC13 (1). Cf56a is identical to Kunkel's cDNA probe 8 .

Polymorphism: Constant bands of 14.4, 11.0, 8.1, 6.2 and 1.3 $\mathrm{kb}$ correspond to exons $\mathrm{I}, \mathrm{N}, \mathrm{L}, \mathrm{M}$ and $\mathrm{K}$ respectively of ref (2). The polymorphic band is exon $\mathrm{J}$ (exon $48,1.2+3.9 \mathrm{~kb}$ HindIII bands).

Frequency: Estimated from 149 chromosomes in caucasian British

$\begin{array}{lll}\text { Allele } 1 & 6.7 \mathrm{~kb} & 0.62 \\ \text { Allele 2 } & 6.4 \mathrm{~kb} & 0.25 \\ \text { Allele } 3 & 4.2 \mathrm{~kb} & 0.13\end{array}$

Chromosomal location: Xp21.

Mendelian inheritance: Codominant segregation of all alleles in a large 4-generation family and 10 nuclear families.

Probe availability: Contact Kay Davies, Molecular Medicine, John Radcliffe Hospital, Oxford OX3 9DU (or ATCC for probe 8).

Other comments: This exon is deleted in $25 \%$ of all Duchenne/Becker dystrophy boys (2). Therefore this RFLP is useful for determining carrier status of at-risk females by showing heterozygosity or apparent non-maternity.

Acknowledgement: We thank Kay Davies for the Cf56a probe.

References: 1. Forrest,S.M., Cross,G.S., Flint,T., Speer,A., Robson,K.J.H. and Davies,K.E. (1988) Genomics 2, 109-114. 2. Read,A.P., Mountford,R.C., Forrest,S.M., Kenwrick,S.J., Davies,K.E. and Harris,R. (1988) Hum. Genet. 80, 152-156.

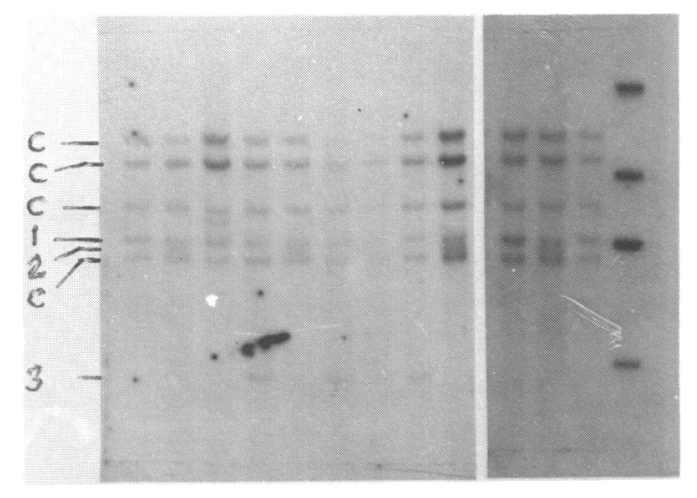

\section{An Alul RFLP detected in the human prion protein (PrP) gene}

\author{
Marsha S.Harris, Evelyn Devine-Gage and \\ Nikolaos K.Robakis ${ }^{1}$ \\ The New York State Institute for Basic Research \\ in Developmental Disabilities, 1050 Forest Hill \\ Road, Staten Island, NY 10314 and ${ }^{1}$ Mt Sinai \\ School of Medicine, Department of Psychiatry \\ and Neurobiology, One Gustave Levy Place, \\ New York, NY 10029, USA
}

Source/description: Probe pEA974(1), contains a 974 bp fragment present in Prp Clone XIV inserted into pBR322. A PvuII RFLP has been previously described (2).

Polymorphism: AluI identifies a two allele polymorphism of either a band at $965 \mathrm{bp}$, a band at $565 \mathrm{bp}$, or two bands at $965 \mathrm{bp}$ and $565 \mathrm{bp}$.

Frequency: Studied in 14 European Caucasians:

965 bp allele (A1): 0.11

565 bp allele (A2): 0.89

Not polymorphic for: (studied in 14 unrelated European Caucasians)-A total of 46 enzymes have been studied including ApaI, ApaLI, AvaI, AvuI, BalI, BalII, BanI, BamHI, BclI, BglI, and BglII. A complete list of enzymes is available on request.

Chromosomal localisation: the PrP gene has been sublocalized to the $\mathrm{p}$ arm of chromosome 20 (3).

Mendelian inheritance: Mendelian pattern of inheritance was shown in an informative family.

Probe availability: Contact Nikolaos K. Robakis.

Acknowledgement: This work was supported in part by NIH grant 5P01HD22634-03.

References: (1) Robakis et al. (1986) PNAS 83, 6377-6381. (2) Wu et al. (1987) Nucl. Acids Res. 15, 3191. (3) Robakis et al. (1986) BBRC 140, 758-765.

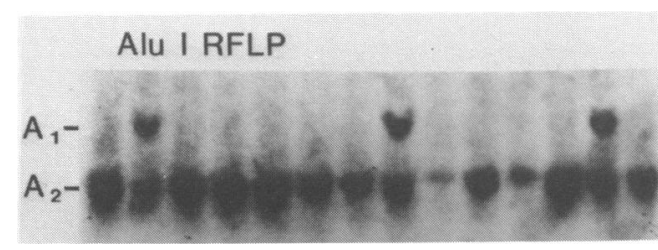

